\title{
ASPEK HUKUM PENGGUNA JASA TRANSPORTASI UDARA KOMERSIL
}

Oleh :

\author{
Nurlely Darwis, SH, MSi \\ Dosen Tetap Fakultas Hukum Universitas Dirgantara Marsekal Suryadarma Jakarta. \\ Kandidat Doktor Ilmu Hukum \\ Email : (nurlely.darwis@gmail.com)
}

\begin{abstract}
:
As an archipelago, Indonesia definitely need transportation services in order to connect the islands one and other, and also between countries. The high rate of consumers has indicated the opportunities of transportation services as a lucrative business. Air transport Enterprises for the mobility of people and goods within and between the countries play role as an encourage and driven instruments of regional growth and developments. Therefore it is necessary to have the clear regulation of rights and responsibilies of the carrier. There should also other special regulations to ensure legal protection for air passengers as has been stated in the Act 8 of Consumer Protection 1991, and the Act 1of Aviation 2009.
\end{abstract}

\begin{abstract}
Abstrak :
Sebagai negara kepulauan, Indonesia sangat membutuhkan peran jasa pengangkutan untuk menghubungkan antara pulau yang satu dengan pulau yang lainya dan juga antara negara. Jumlah konsumen yang begitu besar menunjukkan adanya peluang usaha tranportasi jasa pengangkutan sebagai usaha yang menggiurkan. Usaha jasa transportasi udara bagi mobilitas orang serta barang di dalam negeri maupun luar negeri ini berperan sebagai pendorong dan penggerak pertumbuhan daerah dan pengembangan wilayah, oleh karena itu diperlukan ketentuan hak dan kewajiban yang jelas dari pihak pengangkut. Selain itu diperlukan juga ketentuan khusus lainnya yang menjamin Perlindungan Hukum bagi penumpang pesawat udara sebagaimana hak-hak yang telah tercantum dalam undangundang No. 8 Tahun 1991 tentang Perlindungan Konsumen dan Undang-Undang Nomor 1 Tahun 2009 Tentang Penerbangan.
\end{abstract}

\section{A. Pendahuluan}

Transportasi udara secara umum dapat digambarkan sebagai kebutuhan bagi Indonesia yang merupakan negara kepulauan yang terdiri dari sekitar 13.677 pulau. $^{1}$ Sebagai negara

1 Lembaga Pertahanan Nasional; Kewiraan Untuk Mahasiswa, Jakarta: PT. kepulauan, Indonesia sangat membutuhkan peran jasa pengangkutan untuk menghubungkan antara pulau yang satu dengan pulau yang lainya. Dengan jumlah

Gramedia Pustaka Utama Kerjasama Dengan Direktorat Jenderal Pendidikan Tinggi Depdikbud, 1992, hlm.19. 
konsumen yang begitu besar, suatu usaha tranportasi atau bisnis transportasi jasa pengangkutan merupakan salah satu usaha yang sangat menggiurkan untuk di dirikan, karena sangat diperlukan oleh pemakai jasa untuk menghubungkan antar pulau di Indonesia agar mempermudah dan mempercepat suatu perjalanan dengan lebih efisien.

Pentingnya jasa Transportasi memperlancar gerak roda perekonomian sudah tidak dapat diragukan lagi, mengingat beberapa keuntungan yang dimilikinya, karena bisnis transportasi penerbangan atau jasa angkutan udara merupakan salah satu hal yang paling menantang, dimana Indonesia merupakan pasar yang sangat potensial bagi suatu perusahaan jasa transportasi udara yang ingin menjalankan bisnis tersebut. Beberapa keuntungan yang diberikan oleh jasa angkutan udara antara lain seperti jangkauan yang luas, waktu tempuh yang relatif singkat, tarif yang masih dapat dijangkau oleh masyarakat serta keamanan dan kenyamanan yang diberikan.

Pengangkutan udara diatur dengan Undang-Undang No.1 Tahun 2009 tentang Penerbangan. Pengangkutan udara adalah orang atau badan hukum yang mengadakan perjanjian angkutan untuk mengangkut penumpang dengan pesawat terbang dan dengan menerima suatu imbalan. Angkutan udara diadakan dengan perjanjian antara pihak pihak, dan bentuk tiket penumpang atau tiket bagasi bisa dijadikan tanda bukti telah terjadi perjanjian pengangkutan dan pembayaran biaya angkutan.
Berdasarkan Pasal 2 UU No.1 Tahun 2009 tentang Penerbangan, bahwa penerbangan diselenggarakan berdasarkan asas, (1). Manfaat; (2). Usaha bersama dan kekeluargaan; (3). Adil dan merata; (4). Keseimbangan, keserasian, dan keselarasan; (5). Kepentingan umum;

Keterpaduan; (7). Tegaknya hukum; (8). Kemandirian; (9). Keterbukaan dan anti monopoli; (10). Berwawasan lingkungan hidup; (11). Kedaulatan negara; (12). Kebangsaan; dan (13). Kenusantaraan.

Penerbangan diselenggarakan dengan tujuan:

1. Mewujudkan penyelenggaraan penerbangan yang tertib, teratur, selamat, aman, nyaman, dengan harga yang wajar, dan menghindari praktek persaingan usaha yang tidak sehat;

2. Memperlancar arus perpindahan orang dan/atau barang melalui udara dengan mengutamakan dan melindungi angkutan udara dalam rangka memperlancar kegiatan perekonomian nasional;

3. Membina jiwa kedirgantaraan;

4. Menjunjung kedaulatan negara;

5. Menciptakan daya saing dengan mengembangkan teknologi dan industri angkutan udara nasional;

6. Menunjang, menggerakkan, dan mendorong pencapaian tujuan pembangunan nasional;

7. Memperkukuh kesatuan dan persatuan bangsa dalam rangka perwujudan Wawasan Nusantara;

8. Meningkatkan ketahanan nasional; dan

9. Mempererat hubungan antarbangsa. 
Jenis Angkutan Udara atau kegiatan angkutan udara terdiri atas angkutan udara niaga dalam negeri, dan angkutan udara niaga luar negeri. Bahwa kegiatan angkutan udara niaga dapat dilakukan secara berjadwal dan/atau tidak berjadwal oleh badan usaha angkutan udara niaga nasional dan/atau asing untuk mengangkut penumpang dan kargo atau khusus mengangkut kargo.

Angkutan udara niaga dalam negeri hanya dapat dilakukan oleh badan usaha angkutan udara nasional yang telah mendapat izin usaha angkutan udara niaga. Kegiatan angkutan udara niaga tidak berjadwal yang bersifat sementara dapat dilakukan atas inisiatif instansi Pemerintah dan/atau atas permintaan badan usaha angkutan udara niaga nasional. Kegiatan angkutan udara ini yang dilaksanakan oleh badan usaha angkutan udara niaga berjadwal tidak menyebabkan terganggunya pelayanan pada rute yang menjadi tanggung jawabnya dan pada rute yang masih dilayani oleh badan usaha angkutan udara niaga berjadwal lainnya. Kegiatan angkutan udara niaga tidak berjadwal dapat berupa:

1. Rombongan tertentu yang mempunyai maksud dan tujuan yang sama bukan untuk tujuan wisata (affinity group);

2. Kelompok penumpang yang membeli seluruh atau sebagian kapasitas pesawat untuk melakukan paket perjalanan termasuk pengaturan akomodasi dan transportasi lokal (inclusive tour charter);

3. Seseorang yang membeli seluruh kapasitas pesawat udara untuk kepentingan sendiri (own use charter), betukannya adalah taksi udara (air taxi); atau kegiatan angkutan udara niaga tidak berjadwal lainnya.

\section{B. Permasalahan Bisnis Pada Transportasi Udara}

Untuk merealisasikan bisnis penerbangan pada dasarnya membutuhkan modal yang sangat besar, teknologi tinggi, dan sumber daya manusia yang harus memenuhi kualifikasi tertentu, karena dalam bisnis ini faktor keselamatan konsumen harus menjadi prioritas pertimbangan sebab menyangkut keselamatan manusia.

Dapat dilihat secara fakta bahwa kondisi saat ini bisnis penerbangan di Indonesia menjadi sangat ketat dalam hal aturannya mengingat jumlah maskapai penerbangan yang berdiri semakin banyak. Tumbuhnya maskapai penerbangan yang sangat banyak di Indonesia berawal dari diratifikasinya World Trade Organization/ General Aviation Training $\&$ Testing Service (WTO/GATTs). ${ }^{2}$ oleh Indonesia, dimana dengan diratifikasinya World Trade Organization/ General Aviation Training \& Testing Service tersebut tidak dibenarkan lagi pemerintah Indonesia melakukan monopoli dibidang

2 WTO/GATTs adalah organisasi perdagangan dunia yang merupakan satusatunya badan internasional yang secara khusus mengatur masalah perdagangan antar Negara dengan system perdagangan multilateral. WTO/GATTs, Dikelola oleh: Biro Kerjasama Luar Negeri, Makalah Direktorat Perdagangan dan Perindustrian Multilateral, Ditjen Multilateral Ekubang, Deplu. 2004. 
perusahaan jasa penerbangan. ${ }^{3}$ Dengan demikian para pelaku usaha mulai saling bersaing untuk mendirikan perusahaan angkutan udara, dan dapat dilihat data pada tahun 2016 ada terdapat sekitar 30 maskapai penerbangan baik berjadwal maupun tidak berjadwal yang beroperasi di Indonesia. ${ }^{4}$

Banyaknya perusahaan angkutan udara telah memicu juga persaingan didalam memperoleh pengguna jasa penerbangan yang semakin ketat, dan hal tersebut dapat membuat suatu perusahaan penerbangan dapat memberikan penawaran harga tiket yang relatif lebih murah untuk menarik penumpang sebanyakbanyaknya. Namun di sisi lain, dengan tarif yang murah tersebut sering kali mengabaikan kualitas pelayanan (service), hal ini dapat menimbulkan atau bahkan yang lebih mengkhawatirkan lagi dapat menyebabkan berkurangnya kualitas dalam melakukan pemeliharaan (maintenance) pesawat yang efeknya juga akan mengena pada konsumen dalam hal rawan kecelakaan.

Angkutan udara, sebagai salah satu komponen sistem transportasi nasional, pada hakekatnya mempunyai peranan yang sangat penting dalam penyediaan jasa layanan angkutan dalam negeri

\footnotetext{
3 Saefullah Wiradipradja, "Tanggung Jawab Perusahaan penerbangan Terhadap Penumpang Menurut hukum udara Indonesia", Jurnal hukum Bisnis, Volume 25, No.1, tahun 2006., hal.5.

http://bandarasoekarnohatta.com/daftarnama-maskapaipenerbangan-yangberoperasi- di-indonesia.info; Diakses pada 15 Januari 2017.
}

maupun diluar negeri, terutama dalam rangka menghubungkan daerahdaerah yang sulit dijangkau dengan moda angkutan lain secara cepat dan efisien untuk jarak tertentu. Oleh karena itu, transportasi udara merupakan salah satu sarana yang sangat penting dalam kehidupan manusia. Dengan adanya transportasi udara ternyata mempermudah masyarakat menjalankan kegiatannya secara efektif dan efisien dalam hal penggunaan atau pengiriman barang.

Sebagaimana diketahui, bahwa pesawat udara merupakan salah satu alat pengangkutan yang mempunyai teknologi paling canggih yang pernah diciptakan manusia. Tetapi alat pengangkutan yang paling canggih teknologinya tersebut tidak selamanya mendatangkan rasa aman dan nyaman serta memuaskan bagi penggunanya karena akibat kesalahankesalahan manusia. Salah satu yang sering terjadi adalah banyaknya penundaan penerbangan, pembatalan penerbangan yang dilakukan maskapai penerbangan serta kemungkinan terjadi kecelakaan penerbangan.

Penundaan penerbangan dan pembatalan penerbangan biasanya terjadi akibat adanya hal-hal yang diluar kendali manusia seperti cuaca buruk atau rusaknya sistem pesawat. Tetapi seringnya penundaan penerbangan dan pembatalan penerbangan juga dapat diakibatkan oleh kesalahan manusia sendiri atau human error yang diakibatkan oleh keteledoran pihak manajemen. Terjadinya penundaan dan pembatalan penerbangan dapat merugikan pengguna jasa 
penerbangan dari segi waktu ataupun biaya.

Dalam kenyataan, akhir-akhir ini banyak perusahaan angkutan udara yang selalu melakukan penundaan dan pembatalan penerbangan padahal mereka selalu berbicara masalah ketepatan waktu atau on time performance dalam penerbangan untuk mempromosikan maskapainya. Bahwa akibat terjadinya kecelakaan penerbangan ternyata dapat membuat pengguna jasa penerbangan mulai berpikir secara serius untuk menggunakan jasa penerbangan lagi. Selain itu bila sering terjadi kecelakaan-kecelakaan dalam bentuk sederhana maupun yang fatal pada bagian transportasi udara, hal ini kemungkinan dapat mengakibatkan terjadinya kerugian baik materil maupun immateriel bagi pengguna jasa penerbangan, dan hal ini tentu dapat mengakibatkan efek negatif pada maskapai yang salah satunya bisa dalam bentuk berkurangnya pengguna jasa penerbangan.

Diketahui bahwa penggunaan radio, radar dan alat-alat pengaman mutahir lainya seperti sarana pengatur lalulintas pesawat udara pada dasarnya telah mengupayakan untuk mengurangi banyaknya angka kecelakaan pesawat udara, tetapi semuanya itu pada dasarnya belum mampu untuk meniadakan terjadinya kecelakaan pesawat udara, sebab secanggih apapun teknologi yang ada belum dapat menjamin untuk menghilangkan resiko kecelakaan pesawat terbang.

Mengingat masih banyaknya kemungkinan terjadi kecelakaan pesawat udara maka perusahaan penerbangan dalam hal ini maskapai penerbangan ternyata tidak hanya dihadapkan pada kerugian dengan hancurnya pesawat udara tetapi juga mereka dihadapkan pada ketentuan bahwa pengangkutan atau perusahaan penerbangan harus bertanggung jawab atas kerugian akibat kecelakaan bagi penumpang, sebagaimana tercantum dalam pasal 24 ayat 1 Ordonansi Pengangkutan Udara Stb. 1939:100 (yang selanjutnya disebut OPU) yang berbunyi: "pengangkut bertanggung jawab atas kerugian sebagai akibat dari luka-luka atau akibat lain dari tubuh yang diderita oleh seorang penumpang bila kecelakaan tersebut menimbulkan kerugian itu ada hubunganya dengan pengangkutan udara dan terjadi diatas pesawat terbang atau selama melakukan suatu tindakan dalam hubunganya dengan naik atau turun dari pesawat terbang".

Suatu kecelakaan pesawat udara sebagaimana juga kecelakaankecelakaan lainnya merupakan suatu tragedi yang tidak dapat dielakkan. Menurut E. Suherman dalam artikelnya "Suatu Sistem Tanggung Jawab Yang Adil Bagi Indonesia" mengatakan bahwa korban kecelakaan pesawat udara di Indonesia mengalami penderitaan dua kali, yang pertama karena kecelakaan pesawat udara itu sendiri, sedangkan yang kedua karena adanya kekosongan dalam hukum udara di Indonesia. ${ }^{5}$

Kekosongan disini bukan berarti bahwa tidak adanya suatu pengaturan hukum yang mengaturnya, akan tetapi

${ }^{5}$ E.Suherman 1, Hukum Udara Indonesia dan Internasional, (Bandung: Alumni, 1983), hal. 225 
dalam hal ini kekosongan dalam pengertian tanggung jawab pengangkut sebagai mana diatur dalam hukum udara, baik hukum udara yang lingkupnya nasional maupun hukum udara internasional. Kasus-kasus penerbangan yang ada seperti kecelakaan pesawat, penundaan penerbangan, pembatalan penerbangan karena berbagai alasan, pada dasarnya perlu diteliti dan dicari penyebabnya agar tidak terulang kembali dan dapat memberikan rasa keadilan bagi para pihak.

Untuk itu, tanggung jawab hukum perusahaan jasa penerbangan terhadap penumpang atas beberapa kerugian yang ditimbulkan dapat meliputi beberapa aspek yang antara lain adalah aspek perdata, pidana, administratif, perusahaan pengangkutan udara dan perlindungan konsumen. Pada aspek perdata yang menjadi penekanan utama adalah dalam hal pemberian jasa pengangkutan udara, yang pada realitasnya terdapat hubungan hukum antara para pihak yang bersumber dari perjanjian atau perikatan yang kemudian melahirkan hak dan kewajiban para pihak.

Pokok Permasalahan utama dalam hal ini adalah yang menyangkut tentang pengaturan mengenai hak dan kewajiban dalam perjanjian pengangkutan udara antara maskapai penerbangan dan penumpangnya, selain itu yang paling utama adalah tentang perlindungan hukum bagi penumpang apabila terjadi resiko operasional penerbangan berupa keterlambatan penerbangan, penundaan / pembatalan dan kecelakaan penerbangan. Bahwa permasalahan tersebut secara fakta telah lama dirasakan oleh konsumen transportasi udara namun belum ada keberanian melakukan komplen karena sesungguhnya mereka tidak menyadari bahwa hak-haknya sebagai konsumen telah diabaikan oleh pihak perusahaan transportasi.

Definisi operasional yang perlu dipahami secara umum tentang pengertian dan peristilahan dibidang transportasi udara antara lain mencakup beberapa pengertian yaitu:

1. Maskapai Penerbangan adalah "sebuah organisasi yang menyediakan jasa penerbangan bagi penumpang atau barang. Mereka menyewa atau memiliki pesawat terbang untuk menyediakan jasa tersebut dan dapat membentuk kerjasama atau aliansi dengan maskapai lainya untuk keuntungan bersama". ${ }^{6}$

2. Penerbangan

Domestik "penerbangan sipil yang melayani jalur penerbangan dalam negeri"

3. Penerbangan "segala sesuatu yang berkaitan dengan penggunaan wilayah udara, pesawat udara, bandar udara, angkutan udara, keamanan dan keselamatan penerbangan serta kegiatan dan fasilitas penunjang lain yang terkait. $^{7}$

4. Angkutan udara "setiap kegiatan dengan menggunakan pesawat udara untuk mengangkut

https://id.wikipedia.org/wiki/Maskapai_pene rbangan; diakses pada 15 Januari 2017.

7 Indonesia 1, Undang-undang No. 15 Tahun 1992/ UU No. 1 tahun 2009 Tentang Penerbangan, Ketentuan Umum, LN. Tahun 1992 No.53, TLN. No.3481. 
penumpang, pos, dan kargo untuk satu perjalanan atau lebih dari satu bandar udara ke bandar udara lainya atau beberapa bandar udara". ${ }^{8}$

5. Penumpang angkutan udara "seseorang yang diangkut dengan pesawat terbang berdasarkan persetujuan pengangkutan udara". ${ }^{9}$

6. Perjanjian pengangkutan "suatu perjanjian dimana satu pihak menyanggupi untuk dengan aman membawa orang atau barang dari satu kelain tempat, sedangkan pihak yang lainya menyanggupi akan membayar ongkosnya". ${ }^{10}$

7. Keselamatan Penerbangan "keadaan yang terwujud dari penyelenggaraan penerbangan yang lancar sesuai dengan prosedur operasi dan persyaratan kelaikan teknis terhadap sarana dan prasarana penerbangan beserta penunjangnya".

8. Risiko "ketidak-tentuan (uncertainy) yang mungkin melahirkan peristiwa kerugian (loss). ${ }^{11}$

\section{Hak Dan Kewajiban Pihak Pengangkut Dan Pihak Pemakai Jasa}

Terjadinya kewajiban antara kedua belah pihak dalam hal ini pemakai jasa angkutan dan pengusaha angkutan udara adalah, didahului dengan adanya perjanjian yang dilakukan dan disetujui sebelumnya,

${ }^{8}$ Ibid

9 E. Suherman 2, Tanggung Jawab Pengangkut Dalam Hukum Udara Indonesia, (Bandung: NV. Eresco, 1961), hal.311.

10 R.Subekti, Aneka Perjanjian, Cet.10,(Bandung: PT. Citra Aditya Bakti,1995), hal.69.

${ }^{11}$ Wirjono Pridjodikoro; Hukum Asuransi di Indonesia, PT. Intermasa, 1991, Jakarta, hlm. 7. walaupun perjanjian yang disepakati bersama ini bersifat standar dalam arti berasal dari pihak pengusaha angkutan yang sudah dirumuskan sedemikian rupa sehingga para pemakai jasa hanya menyetujui baik secara diam maupun secara terangterangan.

Berkaitan dengan hak dan kewajiban pihak pengangkut, dasar aturan tersebut sudah diatur di dalam Ordonansi Pengangkutan Udara (OPU), selain itu terdapat pula dalam ketentuan khusus lainnya dengan tidak menyimpang dari ketentuan undang-undang.

Hak pengangkut yang terdapat dalam Ordonansi Pengangkutan Udara antara lain adalah sebagai berikut:

1. Di dalam pasal 7 ayat (1), disebutkan bahwa pengangkut berhak untuk meminta kepada pengirim barang atau untuk membuat surat muatan udara.

2. Di dalam pasal 9, disebutkan bahwa pengangkut berhak meminta kepada pengirim barang untuk membuat surat muatan udara, jika ada beberapa barang.

3. Pengangkut juga berhak menolak pengangkutan penumpang jika ternyata identitas penumpang tidak jelas.

4. Hak pengangkut yang dicantumkan dalam tiket penumpang yaitu hak untuk menyelenggarakan angkutan kepada perusahaan pengangkutan lain, serta pengubah tempat-tempat pemberhentian yang telah disetujui, semuanya tetap ada ditangan pengangkut udara.

5. Hak untuk pembayaran kepada penumpang atau pengirim barang 
atas barang yang telah diangkutnya serta mengadakan peraturan yang perlu untuk pengangkutan dalam batas-batas yang dicantumkan Undang-undang.

Kewajiban pengangkutan udara dalam Ordonansi Pengangkutan Udara adalah sebagai berikut :

1. Pengangkut harus menandatangani surat muatan udara segera setelah muatan barang-barang diterimanya (Pasal 8 ayat 2).

2. Bila pengangkut tidak mungkin melaksanakan perintah dari pengirim, pengangkut harus segera memberitahukan Kepada pengirim (Pasal 15 ayat 3 )

Kewajiban pengangkut pada umumnya antara lain adalah :

1. Mengangkut penumpang atau barang-barang ketempat tujuan yang telah ditentukan.

2. Menjaga keselamatan, keamanan penumpang, bagasi barang dengan sebaik-baiknya.

3. Memberi tiket untuk pengangkutan penumpang dan tiket bagasi.

4. Menjamin pengangkutan tepat pada waktunya.

5. Mentaati ketentuan-ketentuan penerbangan yang berlaku

Hak dari pemakai jasa angkutan penumpang udara pada umumnya adalah: (1). Penumpang atau pemakai jasa angkutan dapat naik pesawat terbang atau udara sampai ke tujuan yang dikehendaki; (2). Penumpang atau ahli waris dapat menuntut ganti rugi apabila mendapat kerugian yang diakibatkan kecelakaan pesawat terbang dalam penerbangan, dan kelalaian pengangkutan.
Kewajiban pemakai jasa angkutan penumpang pada umumnya adalah sebagai berikut: (1). Penumpang wajib membayar biaya angkutan udara atau tiket; (2). Penumpang wajib memberitahu kepada pengangkut mengenai barang-barang yang dibawainya; (3). Penumpang berkewajiban mentaati peraturanperaturan pengangkutan udara serta syarat-syarat perjanjian pengangkutan.

Tanggung Jawab Pengangkut Menurut Undang-Undang No.1 Tahun 2009, adalah "Wajib angkut":

(1). Badan usaha angkutan udara niaga wajib mengangkut orang dan/atau kargo, dan pos setelah disepakatinya perjanjian pengangkutan;

(2). Badan usaha angkutan udara niaga wajib memberikan pelayanan yang layak terhadap setiap pengguna jasa angkutan udara sesuai dengan perjanjian pengangkutan yang disepakati;

(3). Perjanjian pengangkutan dibuktikan dengan tiket penumpang dan dokumen muatan.

Prinsip-Prinsip Tanggung Jawab Pengangkut Udara Terhadap Penumpang, khususnya untuk penumpang dapat disimpulkan dari ketentuan-ketentuan dalam Konvensi Warsawa $^{12}$ dan dalam Ordonansi Pengangkutan Udara adalah :

12 Perjanjian Warsawa Tahun 1929: Pada tanggal 12 oktober 1929 di Warsawa ditandatangani suatu perjanjian yang lengkapnya bernama "Convention for the Unification of Certain Rules Relating to International Carriage by Air", yang lebih 
1. Prinsip Presumption of Liability,

Bahwa seseorang pengangkut dianggap perlu bertanggung jawab untuk kerugian yang ditimbulkan pada penumpang, barang atau bagasi dan pengangkut udara tidak bertanggung jawab hanya bila la dapat membuktikan bahwa ia tidak mungkin dapat menghindarkan kerugian itu. Jadi para pihak yang dirugikan dalam hal ini tidak usah membuktikan adanya kesalahan dari pihak pengangkut. Prinsip ini dapat disimpulkan dengan pasal 29 ayat (1) Ordonansi Pengangkutan Udara yang berbunyi "Pengangkut tidak bertanggung jawab untuk kerugian bila ia membuktikan bahwa ia dan semua orang yang dipekerjakan itu, telah mengambil semua tindakan yang diperlukan untuk menghindarkan kerugian atau bahwa tidak mungkin bagi mereka untuk mengambil tindakan-tindakan itu". Prinsip ini oleh pihak pengangkut dirasakan terlalu berat, sebab pihak pengangkut seolah-olah harus atau selalu bertanggung jawab apabila terjadi kerugian pada penumpang.

\section{Prinsip Limitation of Liability}

Bahwa setiap pengangkut dianggap selalu bertanggung jawab, namun bertanggung jawab itu terbatas sampai jumlah tertentu sesuai dengan ketentuan yang telah diatur

dikenal dengan sebutan "Perjanjian Warsawa ". Perjanjian ini mengatur antara lain dua hal pokok, yaitu, (1). Mengenai Dokumen Angkutan Udara; (2). Mengenai masalah tanggung jawab pengangkut udara Internasional. Pentingnya perjanjian ini ialah ketentuan-ketentuan didalamnya mengatur mengenai limit tanggung jawab ganti rugi . dalam Ordonansi Pengangkutan

Udara maupun Konvensi

Warsawa. Pembatasan tanggung jawab pengangkut udara dalam ordonansi dimaksudkan pembatasan dalam jumlah ganti rugi yang akan dibayarkan. Ordonansi Pengangkutan Udara, pasal yang mengatur pembatasan tanggung jawab untuk penumpang adalah pasal 30 ayat (1), yaitu :

"Pada pengangkutan penumpang, tanggung jawab pengangkut terhadap tiap-tiap penumpang atau terhadap keluarganya yang disebutkan dalam pasal 24 ayat (2) bersama-sama dibatasi sampai jumlah dua belas ribu lima ratus (Rp. 12.500,-). Jika ganti kerugian ditetapkan sebagai suatu bunga, maka jumlah uang pokok yang dibungakan tidak boleh melebihi jumlah di atas".

Pembatasan dan Pembebasan Tanggung Jawab Pengangkut, hal ini diatur dalam pasal 24 ayat (2), pasal 28, pasal 29 ayat (1) dan pasal 33 Ordonansi Pengangkutan Udara. Pasal 30 merupakan pembatasan tanggung jawab yaitu bahwa tanggung jawab pengangkut udara dibatasi sampai jumlah Rp.12.500,- per penumpang. Pasal 24 merupakan pembatasan siapa-siapa saja yang berhak menerima ganti rugi, yang dalam hal ini adalah, suami/istri dari penumpang yang tewas, anak atau anak-anaknya dari si mati orang tua dari si mati.

Pasal 28 menentukan bahwa pengangkut udara tidak bertanggung jawab dalam hal kelambatan, pasal ini berbunyi: 
"Jika tidak ada persetujuan Ijin, maka pengangkut bertanggung jawab untuk kerugian yang timbul karena kelambatan dalam pengangkutan penumpang, bagasi dan barang". Satu pasal lain mengenai pembatasan tanggung jawab pihak pengangkut adalah pasal 33, dimana pasal tersebut menentukan gugatan mengenai tanggung jawab atas dasar apapun juga hanya dapat diajukan dengan syarat-syarat dan batas-batas seperti yang dimaksudkan dalam peraturan ini.

Dengan terbatasnya gugatan mengenai tanggung jawab dari pihak pengangkut, maka terbatas juga tanggung jawab pihak pengangkut. Pembebasan Tanggung Jawab Pengangkut Dalam Ordonansi Pengangkutan Udara yang memuat ketentuan mengenai pembebasan adalah pasal 1 ayat (1), pasal 29 avat (1) dan pasal 36. Pasal 36 menemukan bahwa pengangkut bebas dari tanggungjawabnya dalam hal setelah dua tahun penumpang yang menderita kerugian tidak mengajukan tuntutannya.

Pasal 36 berbunyi:

"Gugatan mengenai tanggung jawab pengangkut harus diajukan dalam jangka waktu dua tahun terakhir mulai saat tibanya di tempat tujuan, atau mulai dari pesawat udara seharusnya tiba, atau mulai pengangkutan udara diputuskan jika tidak ada hak untuk menuntut dihapus". Selain itu ada hal-hal yang membuat pengangkut tidak bertanggung jawab apabila timbul suatu keadaan yang sama sekali tidak diduga sebelumnya, seperti hal nya bahaya perang, sabotase, kebakaran, kerusuhan, kekacauan dalam negeri.

Asuransi udara pada prinsipnya melindungi pihak tertanggung pada umumnya terhadap bahaya-bahaya yang disebabkan atau yang berkaitan dengan digunakannya pesawat udara. Pada umunya asuransi udara dibagi ke dalam tiga golongan, yaitu:

1. Asuransi orang, yaitu penumpang serta awak pesawat (personal insurance),

2. Asuransi kebendaan (property insurance),

3. Asuransi pertanggungjawaban (liability insurance).

Perjanjian asuransi udara dikuasai oleh ketentuan-ketentuan mengenai asuransi pada umunya, berarti berlaku ketentuan-ketentuan dalam BAB IX Buku Kesatu KUHD. Perjanjian asuransi merupakan perjanjian kemungkinan (kansovereenkomst) dengan pasal 1774 KUH Perdata sebagai dasar hukumnya, yang berbunyi:

"suatu perjanjian untunguntungan adalah suatu perbuatan yang hasilnya, mengenai untung ruginya, baik bagi semua pihak, maupun bagi sementara pihak, bergantung pada suatu kejadian yang belum tentu, adalah:1) perjanjian pertanggungan, 2)bunga cagak hidup, 3)perjudian serta pertaruhan. Perjanjian yang pertama diatur didalam $\mathrm{KUH}$ Dagang ". 
Perjanjian terbentuk cukup dengan tercapainya kata sepakat, serta perjanjian asuransi termasuk bentuk konsensual pasal 255 jo $257 \mathrm{KUH}-$ Dagang yang berbunyi:

"Suatu pertanggungan harus dibuat secara tertulis dalam suatu akta yang dinamakan polis".

Asuransi dalam hal ini bertanggung jawab dibidang pengangkutan udara didasarkan atas prinsip terjadinya peristiwa asuransi tersebut, karena mencakup kerugian-kerugian yang terjadi selama jangka waktu asuransi dan dilandasi kerugian sebagaimana ketentuan diatur dengan undangundang Perasuransian ( UU No. 2 tahun 1992 tentang Usaha Perasuransian/ UU No. 40 tahun 2014 tentang Perasuransian).

\section{Perlindungan Konsumen Jasa Penerbangan}

Maskapai penerbangan adalah sebuah organisasi yang menyediakan jasa penerbangan bagi penumpang atau barang. Mereka menyewa atau memiliki pesawat terbang untuk menyediakan jasa tersebut dan dapat membentuk kerja sama atau aliansi dengan maskapai lainnya untuk keuntungan bersama. Konsumen jasa penerbangan adalah setiap orang pemakai jasa maskapai penerbangan yang tersedia dalam masyarakat.

Perlindungan konsumen sebagaimana diatur dalam Undang-Undang Nomor 8 Tahun 1999 tentang Perlindungan Konsumen, adalah segala upaya yang menjamin adanya kepastian hukum untuk memberi perlindungan kepada konsumen. Segala upaya yang menjamin adanya kepastian hukum diharapkan dapat menjadi benteng untuk meniadakan tindakan sewenang-wenang yang merugikan konsumen karena kesewenangwenangan akan mengakibatkan ketidakpastian hukum dan ketidakpastian hukum tidak akan memberikan suatu perlindungan bagi konsumen.

Perlindungan hukum terhadap konsumen menyangkut dalam banyak aspek kehidupan terutama dalam aspek kehidupan konsumen yang begitu banyak mengalami kerugian. Pada dasarnya ada 10 macam hak konsumen sebagaimana diatur dalam UU Perlindungan Konsumen, meliputi antara lain; Hak katas keamanan dan keselamatan; Hak untuk memperoleh informasi; Hak untuk memilih; Hak untuk didengar; Hak untuk memperoleh kebutuhan hidup; Hak untuk memperoleh ganti rugi; Hak untuk memperoleh pendidikan konsumen; Hak untuk memperoleh lingkungan hidup yang bersih dan sehat; Hak untuk mendapatkan barang sesuai dengan nilai tukar yang diberikannya: Hak untuk mendapatkan upaya penyelesaian hukum yang patut.

Hak konsumen yang berkaitan erat dengan kecelakaan pesawat maupun untuk pencegahan kecelakaan tersebut yaitu antara lain; (1). Hak atas keamanan dan keselamatan;(2). Hak untuk memperoleh informasi; (3). Hak untuk memperoleh pendidikan konsumen; (4). Hak untuk memperoleh ganti kerugian. Hak atas keamanan dan keselamatan ini dimaksudkan untuk menjamin keamanan dan keselamatan konsumen dalam penggunaan jasa 
penerbangan yang digunakannya, sehingga konsumen dapat terhindar dari kerugian secara fisik maupun secara psikis apabila menggunakan jasa maskapai penerbangan.

Hak untuk memperoleh informasi yang jelas dan benar agar konsumen dapat memperoleh gambaran yang benar tentang suatu pelayanan dan kondisi jasa penerbangan, karena dengan informasi tersebut konsumen dapat memilih produk yang diinginkan/sesuai kebutuhannya serta terhindar dari kerugian akibat kesalahan dalam penggunaan jasa penerbangan.

Dari uraian tersebut, dapat diketahui bahwa perlindungan hukum bagi konsumen dalam hal ini penumpang pesawat udara oleh pihak maskapai penerbangan sebagai pelaku usaha adalah besar, dan harus dilaksanakan sesuai dengan ketentuan yang berlaku dalam dunia penerbangan.Tetapi dalam prakteknya, banyak hal tentang perlindungan itu yang abaikan dan tidak ditepati oleh pihak penerbangan.

Atas kurangnya perlindungan hukum terhadap penumpang pesawat udara, seharusnya pihak maskapai penerbangan dapat dikenakan sanksi. Melihat kurangnya penanganan terhadap tindakan pihak maskapai penerbangan, penumpang pesawat udara hanya dapat mengikuti prosedur penerbangan yang ada sekalipun hal tersebut dianggap sangat merugikan penumpang sebagai konsumen dan kurangnya rasa tanggung jawab pihak penerbangan.
Berdasarkan Undang-Undang Nomor 1 Tahun 2009 tentang Penerbangan, pembahasan masalah perlindungan hukum bagi konsumen jasa angkutan udara, meskipun khusus dibatasi untuk penumpang bukanlah suatu hal yang mudah. Unsur-unsur perlindungan yang menjadi hak konsumen jasa angkutan dan keseluruhan pengaturan mengenai unsur-unsur itulah yang merupakan perlindungan hukum bagi konsumen yang bila disusun secara sistematis dan integral akan merupakan suatu sistem perlindungan hukum bagi konsumen jasa angkutan udara.

Bahwa pokok dalam suatu sistem perlindungan hukum bagi konsumen jasa angkutan udara adalah kepentingan konsumen karena konsumenlah yang menjadi "Alasan Utama" seluruh kegiatan angkutan udara. Dalam hal ini tanpa konsumen tidak ada justifikasi bagi investasi untuk sarana dan prasaran angkutan udara yang begitu besar. Namun hal ini yang menyangkut hak konsumen seringkali diabaikan.

Suatu sistem perlindungan hukum bagi konsumen jasa angkutan udara adalah suatu sistem yang terdiri dari peraturan perundang-undangan dan prosedur yang mengatur semua aspek yang langsung maupun tidak langsung mengenai kepentingan dari konsumen jasa angkutan udara. Dari sistem perlindungan hukum tersebut dapat dilihat unsur-unsur perlindungan konsumen, mencakup:

(1). Keselamatan penerbangan;

(2). Keamanan penerbangan;

(3). Kenyamanan penerbangan;

(4). Pelayanan penerbangan;

(5). Pertarifan;

(6). Perjanjian angkutan udara. 
Sebagai upaya untuk pencegahan terjadinya kecelakaan pesawat udara, konsumen berhak dipenuhi haknya dalam hak atas keamanan dan keselamatan, hak untuk memperoleh informasi, hak untuk memperoleh pendidikan konsumen. Dalam kaitannya dengan hak atas keamanan dan keselamatan, konsumen jasa penerbangan seharusnya diberikan informasi mengenai pedoman keselamatan/safety guidelines.

Dalam kaitannya dengan hak untuk memperoleh ganti kerugian misalnya dalam hak atas asuransi yang mengacu pada Konvensi Montreal tentang "Unifikasi aturan-aturan terkait penerbangan Internasional", yang menyatakan bahwa pihak maskapai wajib bertanggung jawab secara hukum untuk memberikan pertanggungan kepada penumpang. Konvensi tersebut mengatur bahwa santunan bagi penumpang diberikan dalam dua tahap. Tahap pertama, maskapai wajib membayar ganti rugi hingga 100.000 US \$ atau sekitar Rp1,77 Miliar atas penumpang yang meninggal atau yang terluka dalam kecelakaan pesawat. Tahap kedua, maskapai membayar biaya hidup keluarga yang ditinggalkan, sebagai bentuk iktikad baik perusahaan.

Gambaran tersebut merupakan kajian sempit secara hukum atas hak-hak konsumen dalam kaitan dengan perlindungan konsumen jasa penerbangan. Sebagaimana sempitnya pengetahuan masyarakat tentang problema perlindungan konsumen jasa penerbangan di Indonesia dan umumnya orang mendapati bahwa pihak maskapai penerbangan di
Indonesia masih belum maksimal dalam mengupayakan perlidungan bagi konsumen yang menggunakan jasa penerbangan.

\section{E. Kesimpulan Perlindungan Konsumen Transportasi Udara}

Perlindungan Hukum Penumpang Pesawat Udara Sebagai Konsumen Berdasarkan Undang-Undang Nomor 8 Tahun 1991 dan Undang-Undang Nomor 1 Tahun 2009. Dalam hal ini transportasi merupakan sarana untuk memperlancar roda perekonomian, membuka akses ke daerah pedalaman atau terpencil, memperkukuh persatuan dan kesatuan bangsa, menegakkan kedaulatan negara, serta mempengaruhi semua aspek kehidupan masyarakat.

Pentingnya transportasi tercermin pada semakin meningkatnya kebutuhan jasa angkutan bagi mobilitas orang serta barang di dalam negeri maupun luar negeri, serta berperan sebagai pendorong dan penggerak bagi pertumbuhan daerah dan pengembangan wilayah. Menyadari peran transportasi tersebut, selayaknya penyelenggaraan penerbangan harus ditata dalam suatu kesatuan sistem trasnportasi nasional secara terpadu dan mampu mewujudkan penyediaan jasa transportasi yang seimbang dengan tingkat kebutuhan, selamat, aman, efektif dan efisien. ${ }^{13}$

Undang-Undang Nomor 8 Tahun 1999 tentang Perlindungan

${ }_{13}$ Celina Tri Siwi Kristiyanti, Hukum Perlindungan Konsumen., Jakarta; Sinar Grafika, 2011, hlm. 47. 
Konsumen, Prinsip tentang tanggung jawab merupakan perihal yang sangat penting dalam hukum perlindungan konsumen. Dalam kasus pelanggaran hak konsumen, diperlukan kehatihatian dalam menganalisis siapa yang harus bertanggung jawab dan seberapa jauh tanggung jawab dapat dibebankan kepada pihak terkait.

Sebagai pemakai barang/jasa, konsumen memiliki sejumlah hak dan kewajiban. Pengetahuan tentang hakhak konsumen sangat penting agar orang bisa bertindak sebagai konsumen yang kristis dan mandiri. Tujuannya, jika diperkirakan adanya tindakan yang tidak adil terhadap dirinya, ia secara spontan menyadari akan hal itu. Konsumen kemudian bisa bertindak lebih jauh untuk memperjuangkan hak-haknya. Dengan kata lain, ia tidak hanya tinggal diam saja ketika menyadari bahwa hak-haknya telah dilanggar pelaku usaha. Maka dalam hal ini perlu kiranya ada acuan bagi maskapai penerbangan untuk mengoptimalkan perlindungan konsumen jasa penerbangan, dalam arti konsumen harus dipandang sebagai subyek yang dijunjung harkat dan martabatnya guna menciptakan sinergi antara pihak maskapai penerbangan, pemerintah, dan konsumen dalam menciptakan usaha penerbangan yang layak di Indonesia.

Di Indonesia, besaran ganti kerugian untuk setiap penumpang yang meninggal dunia, cacat tetap, atau luka-luka akibat kejadian angkutan udara di dalam pesawat udara dan/atau naik turun pesawat udara, bagasi tercatat yang hilang, musnah atau rusak yang diakibatkan oleh kegiatan angkutan udara selama kargo berada dalam pengawasan pengangkut, kerusakan atau kehilangan sebagian atau seluruh bagasi tercatat atau kargo yang hilang, musnah, atau rusak dievaluasi paling sedikit satu kali oleh Menteri Perhubungan. ${ }^{14}$ Berdasarkan evaluasi tersebut dapat dilakukan perubahan besaran ganti kerugian, setelah mempertimbangkan saran dan masukan dari menteri yang membidangi urusan keuangan. Ketentuan lebih lanjut tentang batasan ganti kerugian ditetapkan dengan peraturan Menteri Perhubungan.

Pihak yang berhak menerima ganti kerugian diatur dalam Pasal 173 UU No.1 tahun 2009 yang menurut pasal tersebut dalam hal seorang meninggal dunia karena diakibatkan kejadian angkutan udara di dalam pesawat udara dan/atau turun pesawat udara yang berhak menerima ganti kerugian adalah ahli waris penumpang tersebut sesuai dengan ketentuan peraturan perundang-undangan. Dalam hal tidak ada ahli waris yang berhak menerima ganti kerugian, badan usaha angkutan udara niaga menyerahkan ganti kerugian kepada negara setelah dikurangi biaya pengurusan jenazah sesuai dengan ketentuan perundang-undangan.

Selain itu dalam hal gugatan diatur dalam Pasal 176 dan 177 UU No. 1 Tahun 2009. Menurut Pasal 176 UU No 1 Tahun 2009, penumpang,

${ }^{14}$ H.K. Martono, Hukum Penerbangan Berdasarkan Undang-Undang Republik Indonesia Nomor 1 Tahun 2009 Bagian Pertama, Bandung : Mandar Maju, 2009, hlm. 202. 
pemilik bagasi kabin, pemilik bagasi tercatat, pengirim kargo, dan/atau ahli waris penumpang, yang menderita kerugian akibat kejadian angkutan udara di dalam pesawat udara dan/atau naik turun pesawat udara, karena hilang atau rusaknya bagasi kabin yang disebabkan oleh tindakan pengangkut atau orang yang dipekerjakan pengangkut, karena bagasi tercatat hilang, musnah atau rusak yang diakibatkan oleh kegiatan angkutan udara selama bagasi tercatat berada dalam pengawasan pengangkut karena kargo hilang, musnah atau rusak yang diakibatkan oleh kegiatan angkutan udara selama kargo berada dalam pengawasan pengangkut, dan ahli waris penumpang dapat mengajukan gugatan melalui pengadilan negeri di wilayah Indonesia dengan menggunakan hukum Indonesia.

Gugatan dapat diajukan ke pengadilan negeri tempat pembelian tiket, pengiriman barang, domisili kantor pengangkut, kantor cabang dan domisili tergugat dan penggugat di seluruh wilayah Republik Indonesia. Hal tersebut dimaksudkan untuk memberi kemudahan kepada korban. Hak untuk menggugat kerugian yang meliputi untuk penumpang adalah meninggal dunia, luka-luka tubuh, keterlambatan dan tidak terangkut, dan untuk bagasi tercatat dan kargo adalah hilang, musnah, rusak, terlambat dan tidak terangkut sesuai dengan jadwal yang telah ditentukan yang diderita penumpang atau pengirim kepada pengangkut dinyatakan kadaluarsa dalam janka waktu 2 tahun terhitung mulai tanggal seharusnya kargo dan bagasi tersebut tiba di tempat tujuan.

\section{Daftar Pustaka}

Buku

Celina Tri Siwi Kristiyanti, Hukum Perlindungan Konsumen., Jakarta; Sinar Grafika, 2011;

E. Suherman 2, Tanggung Jawab Pengangkut Dalam Hukum Udara Indonesia, (Bandung: NV. Eresco, 1961);

Saefullah Wiradipradja, "Tanggung Jawab Perusahaan penerbangan Terhadap Penumpang Menurut hukum udara Indonesia", Jurnal hukum Bisnis, Volume 25, No.1, tahun 2006;

H.K. Martono, Hukum Penerbangan Berdasarkan Undang-Undang Republik Indonesia Nomor 1 Tahun 2009 Bagian Pertama, Bandung: Mandar Maju, 2009;

R. Subekti, Aneka Perjanjian, Cet.10, (Bandung: PT. Citra Aditya Bakti,1995);

Lembaga Pertahanan Nasional; Kewiraan Untuk Mahasiswa, Jakarta: PT. Gramedia Pustaka Utama Kerjasama Dengan Direktorat Jenderal Pendidikan Tinggi Depdikbud, 1992.

\section{Perundang-undangan:}

Kitab Undang-undang Hukum Pidana Kitab Undang-undang Hukum Perdata Kitab Undang-undang Hukum Dagang Ordonansi Pengangkutan Udara tentang Ketentuan-ketentuan pengangkutan udara dalam negeri; 
Undang-undang No. 15 Tahun 1992/ UU

No. 1 tahun 2009 Tentang

Penerbangan, Ketentuan

Umum, LN. Tahun 1992

No.53, TLN. No.3481.

Undang-Undang Nomor 8 Tahun 1999

tentang Perlindungan

Konsumen;

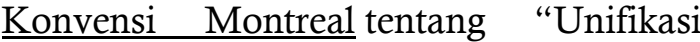
aturan - aturan terkait penerbangan Internasional",

Konvensi Warsawa

Internet:

https://id.wikipedia.org/wiki/Maskapai penerbangan; diakses pada 15 Januari 2017.

http://bandarasoekarnohatta.com/daftarnama-maskapai- penerbanganyang- beroperasi- diindonesia.info; Diakses pada 15 Januari 2017. 